\title{
ANALISIS KESADARAN MAHASISWA UMRI TERKAIT PENGGUNAAN TEKNOLOGI \& MEDIA SOSIAL TERHADAP BAHAYA CYBERCRIME
}

\author{
Soni $^{1}$, Afdhil Hafid ${ }^{2}$, Didik Sudyana ${ }^{3}$ \\ ${ }^{12}$ Teknik Informatika, Fakultas Ilmu Komputer, Universitas Muhammdiyah Riau \\ ${ }^{2}$ Teknik Informatika, STMIK AMIK Riau

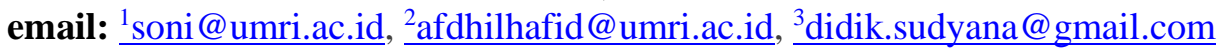

\begin{abstract}
Students are one of the many users of technology and the internet. Based on data from the Association of Indonesian Internet Service Providers, it states that as many as $100 \%$ of student respondents stated using the internet every day. So that the potential for students to become victims of cyber crime continues to increase. This is because many internet users are not careful in using it. Cyber crimes that often occur include identity theft, kidnapping, online fraud, burglary and so forth. During this time many users who write their personal identity on social media, not even a few who post about the location they visit. Then many students are fond of using free wifi. Cybercrime will not occur if there is vigilance and caution from its users. Students should be able to realize the negative effects of cyberspace. For this reason, an analysis is needed regarding the presence of social media users. In this research, analysis of student awareness in the informatics engineering study program, computer science faculty, Muhammadiyah University of Riau to find out how much the level of student awareness about the dangers of cybercrime is based on the social media and user awareness categories. From the results of the study, it was concluded that students of the Department of Informatics had a fairly good level of awareness. This is evidenced from the average results obtained in the social media category, $83.4 \%$ of students have a fairly good awareness while the average user awareness category of $72.7 \%$. However, the university, faculty and study programs must still provide assistance, education or outreach to those who do not have a good level of vigilance because there are still a few percent who still do not have a good level of vigilance.
\end{abstract}

Keywords: cybercrime, students, awareness, social media, internet

\begin{abstract}
Abstrak
Mahasiswa merupakan salah satu pengguna teknologi dan internet yang cukup banyak. Berdasarkan data dari Asosiasi Penyedia Jasa Internet Indonesia, menyebutkan bahwa sebanyak 100\% responden dari mahasiswa menyatakan menggunakan internet setiap harinya. Sehingga potensi mahasiswa menjadi korban kejahatan siber pun terus meningkat. Hal ini disebabkan karena banyak pengguna internet yang tidak berhati-hati dalam menggunakannya. Kejahatan cyber yang sering terjadi diantaranya adalah pencurian identitas, pembulian, penipuan online, perampokan dan lain sebagainya. Selama ini banyak pengguna yang menuliskan identitas pribadinya di media social, bahkan tidak sedikit yang memposting tentang lokasi yang mereka kunjungi. Kemudian banyak mahasiswa yang gemar menggunakan wifi gratis. Kejahatan cyber tidak akan terjadi jika ada kewaspadaan dan kehati-hati dari para penggunanya. Seharusnya para mahasiswa dapat menyadari dampak negatif dari dunia maya. Untuk itu perlu dilakukan analisis terkait kesadaarn pengguna media sosial. Dalam penelitian ini, analisis kesadaran mahasiswa di program studi teknik informatika, fakultas ilmu komputer, universitas muhammadiyah riau untuk mengetahui seberapa besar tingkat kesadaran mahasiswa tentang bahaya cybercrime didasarkan pada kategori media sosial dan kesadaran pengguna. Dari hasil penelitian, disimpulkan bahwa mahasiswa Jurusan Teknik Informatika memiliki tingkat kesadaran yang cukup baik. Hal ini dibuktikan dari hasil rata-rata yang diperoleh pada kategori media sosial, 83,4\% mahasiswa mempunyai kesadaran yang cukup baik sedangkan pada kategori kesadaran pengguna rata-rata sebanyak 72,7\%. Namun pihak universitas, fakultas dan juga program studi tetap harus memberikan pendampingan, edukasi ataupun sosialisasi bagi yang belum memiliki tingkat kewaspadaan yang baik karena masih ada beberapa persen masih masih belum mempunyai tingkat kewaspadaan yang baik.
\end{abstract}

Kata kunci: cybercrime, mahasiswa, kesadaran, media social, internet 


\section{PENDAHULUAN}

Perkembangan teknologi informasi dan internet semakin berkembang pesat. Hal tersebut juga mempengaruhi penggunaan gadget di kalangan mahasiwa bahkan masyarakat luas. Bahkan hampir dikatakan semua mahasiswa menggunakan internet dan media social setiap hari nya. Penggunaan gadget juga tidak terlepas dengan adanya akses internet, sosial media untuk menjelajah dunia maya. Apalagi dizaman yang serba teknologi ini semua aktifitas telah melibatkan internet dan juga media social. Dimulai dari membuka mata hingga malam hari sebelum tidur juga semua orang telah menggunakan gadget sebagai media komunikasi dan berbagi informasi dan komunikasi. Aktifitas yang sering digunakan adalah browsing, chating, mengakses gojek, grab dan masih banyak lagi aktifitas lainnya. Banyaknya akses internet yang dilakukan akan mengundang cybercrime.

Kejahatan cyber (cybercrime) juga saat ini semakin terus meningkat, bahkan berdasarkan berdasarkan data yang diperoleh Okezone dari Direktorat Tindak Pidana Kejahatan Cyber / cybercrime (Dit Tipidsiber) Bareskrim Polri Sepanjang Tahun 2017, yakni JanuariOktober, jajaran Polri di Indonesia menangani 1.763 kasus kejahatan siber [1]. Dalam pemaparan data okezone tersebut, sepanjang 2017 tersebut kasus cybercrime yang paling sering terjadi adalah perkara penipuan dengan wadah teknologi, pornografi, penghinaan dan juga pencemaran nama baik. Berdasarkan statistik yang telah dipaparkan okezone tersebut dapat terlihat pesatnya perkembangan cybercrime diindonesia.

Perkembangan yang pesat dalam teknologi internet menyebabkan kejahatan baru dibidang itu juga muncul, misalnya kejahatan manipulasi data, spionase, sabotase, provokasi, money laundering, hacking,pencurian software maupun perusakan hardware dan berbagai macam lainnya. Bahkan laju kejahatan melalui jaringan internet (cybercrime) tidak diikuti dengan kemampuan pemerintah untuk mengimbanginya sehingga sulit untuk mengedalikannya. Munculnya beberapa kasus cybercrime di Indonesia telah menjadi ancaman stabilitas Kamtibmas dengan eskalatif yang cukup tinggi. Pemerintah dengan perangkat hukumnya belum mampu mengimbangi teknik kejahatan yang dilakukan dengan teknologi computer khususnya di jaringan internet dan internet[2].

Kejahatan cyber yang sering terjadi diantaranya adalah pencurian identitas, pembulian, penipuan online, perampokan dan lain sebagainya. Seringkali kejahatan cyber ini terjadi dikarenakan banyaknya pengguna yang kurang sadar nya pengguna terhadap penggunaan media sosial. Selama ini banyak pengguna yang menuliskan identitas pribadinya di media social, bahkan tidak sedikit yang memposting tentang lokasi yang mereka kunjungi. Kejahatan cyber tidak akan terjadi jika ada kewaspadaan dan kehati-hati dari para penggunanya. Untuk itu perlu dilakukan analisis terkait kesadaarn pengguna media sosial[3].

Berikut ini akan dibahas ulasan tentang penelitian yang telah dilakukan sebelumnya berkaitan dengan penggunaan teknologi. Diawali dengan penelitian mengenai kesadaran hukum mahasiswa terhadap teknologi dan perkembangannya. Dalam penelitiannya menghasilkan bahwa kebanyakan mahasiswa yang hampir sebanyak 95\% mahasiswa selalu mengunakan handphone dan laptop sebagai medianya untuk berteknologi. Kemudian dari hasil penelitiannya juga menghasilkan bahwa beberapa dari mereka mengatakan bahwa mereka harus mematuhi peraturan didalam UU ITE, dan tidak boleh sembarangan menyebarkan informasi yang belum tentu kebenarannya [4]

Penelitian selanjutnya dilakukan oleh [5] melakukan penelitian mengenai kejahatan kartu kredit, kejahatan pencurian data kartu kredit yang terjadi selama ini dilakukan oleh oknum-oknum yang mengerti dan paham tentang mekanisme transaksi dan teknis jaringan dalam bank yang dituju sebagai objek pembobolan, hal ini memungkinkan adanya pihak yang turut andil melakukan pencurian data kartu kredit. Pihak-pihak yang melakukan pencurian data kartu kredit tersebut menggunakan modus operandi mulai dari pembelian data nasabah, pemalsuan dokumen, pembukuan ganda hingga menyiapkan situs online palsu.

Penelitian lain yang dilakukan [6] mengatakan bahwa terdapat kasus cybercrime banyak dialami oleh kaum perempuan yang berkaitan dengan love scam, pola komunikasi 
yang dilancarkan pelaku cybercrime (scammers) yang baru dikenal korban justru lebih dipercaya, dibanding komunikasi langsung dari orang yang telah dikenal dekat. Penulis melakukan penelitian yang bertujuan untuk mendeskripsikan pola komunikasi dalam kasus cybercrime. Para pelaku biasanya mengambil data-data korban melalui media sosial yang dimiliki oleh korban.

Penelitian dengan judul "Cybercrime over Internet Love Scams in Malaysia: A Discussion on the Theoretical Perspectives, Connecting Factors and Keys to the Problem". Penelitiannya menyimpulkan bahwa secara keseluruhan, dilihat dari empat teori; kantianisme, undang-undang dan peraturan utilitarianisme, dan kontrak sosial yang disepakati aksi love scammers tidak hanya melanggar hukum, tapi juga moral. Sangat penting untuk memiliki kerangka kemitraan kolaborasi yang menghubungkan kantor kedutaan dengan polisi dan departemen imigrasi untuk memerangi disalahgunakan visa pelajar. Yang lebih penting juga adalah individu itu sendiri untuk dilengkapi diri dengan pengetahuan untuk tidak pernah berbagi informasi pribadi mereka dengan siapapun juga dengan berlatih beberapa langkah pencegahan sebelum ditipu.

Selain penelitian diatas [8] juga melakukan penelitian dengan menganalisa bahwa banyak orang yang melakukan percakapan dengan orang tak dikenal, bahkan ada yang sampai menyatakan sebagai sepasang kekasih. Korban yang menjadi korban love scan juga orang yang juga berpendidikan. Dalam penelitiannya juga mengatakan bahwa pendidikan dan pekerjaan tidak dapat memberikan satu jaminan bahawa mereka tidak akan terkena kasus love scam. Seharusnya media social itu digunakan untuk hal hal yang mendidik, dalam berdunia maya masyarakat juga harus memiliki nilai moral dan etika dalammenggunakan serta memanfaatkan media sosial untuk memudahkan urusannya.

Kejahatan cyber tidak akan terjadi apabila pengguna internet berhati-hati dan waspada ketika menggunakan internet tersebut. Namun sayangnya banyak pengguna internet yang tidak berhati-hati dalam menggunakannya. [3]. Kejahatan cyber yang sering terjadi diantaranya adalah pencurian identitas, pembulian, penipuan online, perampokan dan lain sebagainya. Selama ini banyak pengguna yang menuliskan identitas pribadinya di media social, bahkan tidak sedikit yang memposting tentang lokasi yang mereka kunjungi. Kemudian banyak mahasiswa yang gemar menggunakan wifi gratis Kejahatan cyber tidak akan terjadi jika ada kewaspadaan dan kehati-hati dari para penggunanya. Seharusnya para mahasiswa dapat menyadari dampak negatif dari dunia maya.

Untuk itu perlu dilakukan analisis terkait kesadaarn pengguna media sosial.Dalam melakukan penelitian ini nantinya akan dilakukan analisis terhadap kesadaran mahasiswa universita muhammadiyah riau dengan melakukan penyebaran kuisioner fakultas dan program studi di universitas muhammadiyah riau. Yang akan berguna untuk mengetahui seberapa besar tingkat kesadaran mahasiswa universitas muhammadiyah riau terhadap cybercrime. Hasil akhir dari penelitian ini adalah untuk mengetahui berapa persenkan tingkat kesadaran mahasiswa universitas muhammadiyah riau terhadap cybercrime. Sehingga dapat menambah kewaspadaan dan mahasiswa lebih berhati-hati lagi dalam menggunakan internet dan media social.

\section{METODE PENELITIAN}

Metode dan tahapan penelitian dapat digambarkan seperti pada Gambar 1 di bawah ini:

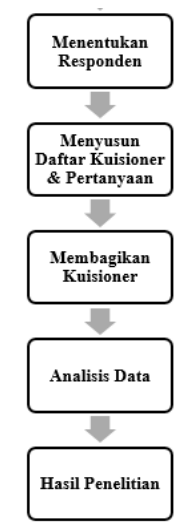

Gambar 1 Metodologi Penelitian 


\section{HASIL DAN PEMBAHASAN}

\subsection{Menentukan responden}

Responden dipilih dari Fakultas Ilmu Komputer Prodi Teknik Informatika Universitas Muhammadiyah Riau. Saat ini jumlah populasi mahasiswa prodi teknik informatika adalah 574 orang. Dalam menentukan jumlah responden, digunakan Tabel Isaac dan Michael dengan tingkat kesalahan adalah sebesar 5\%. Maka dengan total populasi 574 orang, berdasarkan tabel Isaac dan Michael, yang mendekati 574 orang adalah 600 orang dengan sampel minimum 221 orang. Sehingga pada penelitian ini ditetapkan menggunakan sampel minimum sebanyak 221 orang.

Dalam penentuan pemilihan sample, digunakan metode Simple Random Sampling. Sehingga sampel dipilih secara acak tanpa memperhatikan tingkat semester, pengetahuan, dan lain sebagainya.

\subsection{Menyusun daftar kuisioner dan pertanyaan}

Dalam menyusun daftar pertanyaan terkait analisis kesadaran mahasiswa, kuisioner terbagi menjadi lima instrumen, yaitu data pribadi, media sosial, penipuan online, dan kesadaran pengguna. Adapun detail daftar pertanyaan yang telah disusun terdapat dalam pertanyaan kuisioner berikut:

Table 1. Daftar Pertanyaan

\begin{tabular}{|c|cc|}
\hline \multicolumn{2}{|c|}{ Personal Information } \\
\hline 1 & Jenis Kelamin. \\
& a. & Laki-laki \\
& b. & Perempuan \\
\hline 2 & Berapakah umur anda sekarang 17-19 \\
& a. & $20-22$ \\
& b. & $23-25$ \\
& c. & $26-28$ \\
& d. & diatas 29 \\
\hline
\end{tabular}

\begin{tabular}{|c|c|}
\hline & SOCIAL MEDIA \\
\hline 1 & $\begin{array}{l}\text { Dalam sehari berapa lama anda mengakses } \\
\text { internet Below } 2 \text { hours } \\
\text { a. Dibawah } 2 \text { jam } \\
\text { b. } 3-5 \text { jam } \\
\text { c. } \quad \text { Diatas } 6 \text { jam }\end{array}$ \\
\hline 2 & $\begin{array}{l}\text { Apa yang sering anda akses di internet [jawaban } \\
\text { boleh lebih dari 1] ? } \\
\text { a. Media sosial } \\
\text { b. Online shoping } \\
\text { c. Browsing } \\
\text { d. Game online } \\
\text { e. Lainnya }\end{array}$ \\
\hline
\end{tabular}

\begin{tabular}{|c|c|}
\hline 3 & $\begin{array}{l}\text { Pilih sosial media yang anda miliki dan paling } \\
\text { sering anda gunakan sesuai pilihan dibawah ini } \\
\text { [jawaban boleh lebih dari 1]? } \\
\text { a. Facebook } \\
\text { b. Google Plus } \\
\text { c. Twitter } \\
\text { d. Instagram } \\
\text { e. Path } \\
\text { f. Line } \\
\text { g. Ask.fm } \\
\text { h. Yang lain: }\end{array}$ \\
\hline 4 & $\begin{array}{l}\text { Apakah anda memberikan identitas seperti } \\
\text { alamat rumah, tanggal lahir, nomor handphone } \\
\text { di halaman profile anda? } \\
\text { a. Ya } \\
\text { b. Tidak }\end{array}$ \\
\hline 5 & $\begin{array}{l}\text { Apakah anda memberitahukan tentang apa yang } \\
\text { sedang anda alami } \\
\text { a. Ya } \\
\text { b. Tidak }\end{array}$ \\
\hline 6 & $\begin{array}{l}\text { Apakah anda sering memberitahukan lokasi } \\
\text { yang sedang anda kunjungi via media } \\
\text { sosial?Often } \\
\text { c. Sering } \\
\text { d. Jarang } \\
\text { e. Tidak Pernah }\end{array}$ \\
\hline 7 & $\begin{array}{l}\text { Apakah ada data rahasia dan pribadi (seperti } \\
\text { photo rahasia, chat-chat rahasia) anda di media } \\
\text { sosial yang jika itu diketahui publik akan } \\
\text { menjadikan hal buruk untuk anda? } \\
\text { a. Ya } \\
\text { b. Tidak ada }\end{array}$ \\
\hline 8 & $\begin{array}{l}\text { Ketika ada permintaan pertemanan di media } \\
\text { sosial anda, apa tanggapan anda? } \\
\text { a. Langsung menerimanya } \\
\text { b. Dicek dulu profil yang meminta } \\
\text { pertemanan, jika tidak kenal maka } \\
\text { tidak diterima }\end{array}$ \\
\hline 9 & $\begin{array}{l}\text { Apakah anda memberikan informasi pribadi } \\
\text { (seperti nama orang tua, alamat rumah, nomor } \\
\text { handphone, atau tentang pribadi anda) ke } \\
\text { seseorang yang baru anda kenal ketika sedang } \\
\text { chatting? } \\
\text { a. Ya } \\
\text { b. Tidak }\end{array}$ \\
\hline 10 & $\begin{array}{l}\text { Jika orang yang anda baru kenal via chat tersebut } \\
\text { mengajak bertemu, apakah anda mau bertemu } \\
\text { dengannya? } \\
\text { c. Ya, langsung pergi sendiri saja } \\
\text { d. Ya, pergi tapi mengajak teman anda } \\
\text { untuk menemani } \\
\text { e. Tidak Mau }\end{array}$ \\
\hline 11 & $\begin{array}{l}\text { Apakah media sosial anda pernah di hack oleh } \\
\text { orang lain? } \\
\text { a. Pernah } \\
\text { b. Tidak Pernah }\end{array}$ \\
\hline
\end{tabular}




\begin{tabular}{|l|l|}
\hline \multicolumn{2}{|l|}{ Email } \\
\hline 1 & $\begin{array}{l}\text { Ketika media sosial anda dihack apakah hacker } \\
\text { memanfaatkan media sosial anda untuk } \\
\text { menghubungi ataupun menipu teman anda? } \\
\text { a. Ya } \\
\text { b. Tidak } \\
\text { Jika tidak, sebutkan apa yang dilakukan hacker } \\
\text { dengan akun anda ........... }\end{array}$ \\
\hline 2 & $\begin{array}{l}\text { Apakah anda mempunyai data yang penting dan } \\
\text { rahasia dalam email anda? } \\
\text { a. Punya } \\
\text { b. Tiak Punya }\end{array}$ \\
\hline 3 & $\begin{array}{l}\text { Seberapa penting email yang anda miliki saat ini } \\
\text { bagi anda? } \\
\text { a. Sangat Penting } \\
\text { b. Penting } \\
\text { c. Biasa Saja } \\
\text { d. Tidak Penting }\end{array}$ \\
\hline 4 & $\begin{array}{l}\text { Apakah semua akun-akun yang anda miliki (seperti } \\
\text { media sosial, online shopping) terintegrasi dengan } \\
\text { satu email ? } \\
\text { a. Ya } \\
\text { b. Tidak }\end{array}$ \\
\hline
\end{tabular}

\begin{tabular}{|c|c|}
\hline \multicolumn{2}{|c|}{ Kesadaran Pengguna } \\
\hline 1 & $\begin{array}{l}\text { Apakah anda tahu data kartu kredit anda bisa dicuri } \\
\text { via online dan digunakan oleh pihak yang tidak } \\
\text { bertanggung jawab? } \\
\text { a. Tahu } \\
\text { b. Tidak, baru mengetahuinya saat ini }\end{array}$ \\
\hline 2 & $\begin{array}{l}\text { Apakah anda tahu bahwa dengan memberikan } \\
\text { data-data pribadi anda ke internet dapat membuat } \\
\text { anda menjadi salah satu target korban kejahatan } \\
\text { dan penipuan online? } \\
\text { a. Tahu } \\
\text { b. Tidak, baru mengetahuinya saat ini } \\
\end{array}$ \\
\hline 3 & $\begin{array}{l}\text { Apakah anda tahu jika data anda (seperti password } \\
\text { akun) bisa dicuri ketika anda mengakses publik } \\
\text { wifi? } \\
\text { a. Tahu } \\
\text { b. Tidak, baru mengetahuinya saat ini }\end{array}$ \\
\hline 4 & $\begin{array}{l}\text { Pilih tindakan dibawah ini yang anda gunakan } \\
\text { untuk akun-akun internet (email, media sosial, } \\
\text { online shopping,dll) yang anda miliki ! } \\
\text { a. Menggunakan rekomendasi keamanan } \\
\text { yang disarankan penyedia } \\
\text { b. Menggunakan kombinasi password yang } \\
\text { disarankan (gabungan huruf, angka, } \\
\text { simbol) } \\
\text { c. Mengabaikan rekomendasi keamanan } \\
\text { yang disarankan karena ribet } \\
\text { d. Password yang gampang saja karena } \\
\text { lebih mudah diingat (password seperti } \\
\text { tanggal lahir, nama pacar, tanggal jadian) } \\
\text { e. Tidak mementingkan hal diatas, yang } \\
\text { penting punya akun dan bisa digunakan. }\end{array}$ \\
\hline
\end{tabular}

\subsection{Membagikan kuisioner}

Pembagian kuisioner dilakukan dengan menyebarkan kuisioner kepada mahasiswa fakultas ilmu komputer program studi teknik informatika.

\subsection{Analisis Data}

Berdasarkan hasil data kuisioner yang diperoleh, diketahui bahwa terdapat 316 orang mahasiswa, yang berasal dari mahasiswa fakultas ilmu komputer, program studi teknik informatika universitas muhammadiyah riau. Yang terdiri dari $204(64,6 \%)$ berjenis kelamin laki-laki sedangkan sisanya sebanyak 112 $(35,4 \%)$ berjenis kelamin perempuan Jenis Kelamin Responder

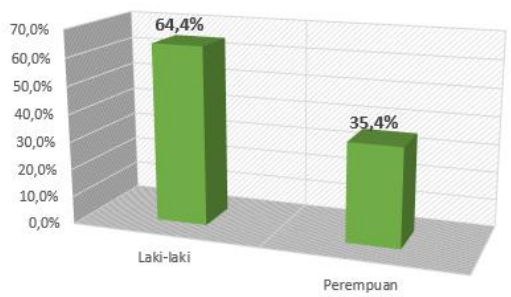

Gambar 2 Persentase jenis kelamin respon

Pada kategori media sosial, angka penggunaan internet perharinya pada kalangan mahasiswa cukup tinggi. Dari angket kuisioner yang diperoleh sebanyak 162 mahasiswa $(51,3 \%)$ mengakses internet rata 3-5 jam sehari, pada posisi kedua 121 mahasiswa $(38,3 \%)$ mengakses internet diatas 6 jam sedangkan sisanya 33 mahasiswa $(10,4 \%)$ hanya menggunakan internet selama 2 jam saja. Ketika menggunakan internet kebanyakan dari mereka lebih banyak menggunakannya untuk bermedia social, yang dapat dilihat pada gambaer berikut :

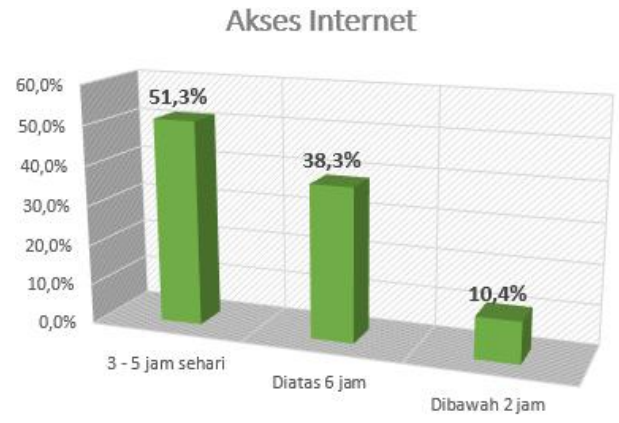

Gambar 3 Persentase penggunaan akses internet

Media sosial yang sangat populer digunakan oleh mahasiswa yaitu Instagram (83.8\%) dan Facebook (44.8\%). Sehingga dapat terlihat bahwa penggunaan internet untuk media sosial sangat masif digunakan oleh kalangan mahasiswa. Dan media sosial instagram menduduki posisi paling banyak diminati oleh kalangan mahasiswa.

Berdasarkan data kuisioner, didapatkan data bahwa rata-rata mahasiswa memiliki tingkat kewaspadaan yang cukup baik dalam 
menggunakan media sosial. Hal ini terlihat dari hasil indikator yang terdapat dalam kategori media sosial, memiliki nilai yang sangat baik, yang dapat dilihat pada tabel berikut:

Table 2. Rangkuman Data Kategori Media Sosial

\begin{tabular}{|l|l|l|}
\hline \multirow{2}{*}{ Media Sosial } & \multicolumn{2}{|l|}{ Jawaban } \\
\cline { 2 - 3 } & $\begin{array}{l}\text { Yes } \\
\text { (\%) }\end{array}$ & $\begin{array}{l}\text { No } \\
\text { (\%) }\end{array}$ \\
\hline $\begin{array}{l}\text { Membagikan identitas pribadi } \\
\text { pada halaman profil media } \\
\text { sosial }\end{array}$ & 36.2 & 63.8 \\
\hline $\begin{array}{l}\text { Membagikan situasi perasaan } \\
\text { terkini yang sedang dialami }\end{array}$ & 18.4 & 81.6 \\
\hline $\begin{array}{l}\text { Memiliki data rahasia dan } \\
\text { pribadi yang jika diketahui } \\
\text { public berdampak buruk bagi } \\
\text { pengguna }\end{array}$ & 15.6 & 84.8 \\
\hline $\begin{array}{l}\text { Menerima pertemanan dari } \\
\text { orang yang tidak dikenal di } \\
\text { media social }\end{array}$ & 6.3 & 93.7 \\
\hline $\begin{array}{l}\text { Membagikan informasi pribadi } \\
\text { kepada orang baru melalui } \\
\text { chatting }\end{array}$ & 2.9 & 97.1 \\
\hline
\end{tabular}

Selain itu, sebanyak $18.4 \%$ mahasiswa juga menyatakan bahwa mereka tidak pernah memberitahukan lokasi terkini yang mereka kunjungi, dan sebanyak $76.2 \%$ menyatakan jarang memberitahukan. Hanya $5.4 \%$ yang menyatakan sering memberitahukan lokasi terkini. Sehingga secara keseluruhan, mahasiswa UMRI sudah memiliki pemahaman yang baik terkait kewaspadaan dalam menggunakan media social.

\section{Memberitahukan lokasi yang dikunjungi via mendia sosial}

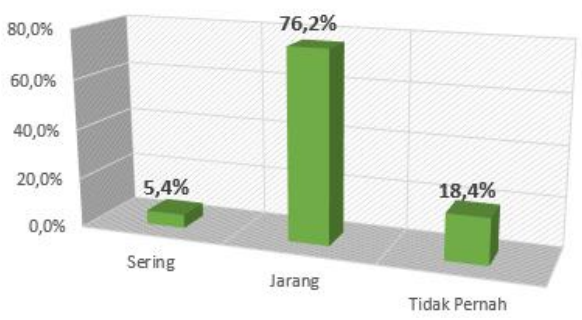

Gambar 4 Persentase Pemberitahuan tag lokasi

Namun berdasarkan data kuisioner, terdapat 28.3\% mahasiswa menyatakan bahwa media social mereka pernah dihack oleh orang yang tidak bertanggung jawab dan $27.9 \%$ menyatakan akun mereka yang dihack telah digunakan untuk tindak kejahatan penipuan dengan menghubungi daftar pertemanan yang ada di media social mereka.

Selanjutnya, dari kuisioner juga didapatkan bahwa 93,7\% mahasiswa jika ada pertemanan dalam media socialnya mereka mengecek terlebih profil yang meminta pertemanan, jika tidak kenal maka tidak diterima. sedangkan $6,3 \%$ langusng menerimanya jika ada yang meminta pertemanan. Dan jika ada orang baru dikenal mengajak bertemu sebanyak $65,2 \%$ yang langsung menolak untuk bertemu, 30,7\% mau bertemu tetapi mengajak teman untuk menemaninya, sedangkan $4,1 \%$ lainnya mau bertemua sendiri tanpa mengajak teman untuk menemaninya.

\section{Orang baru kenal melaui chat mengajak bertemu}

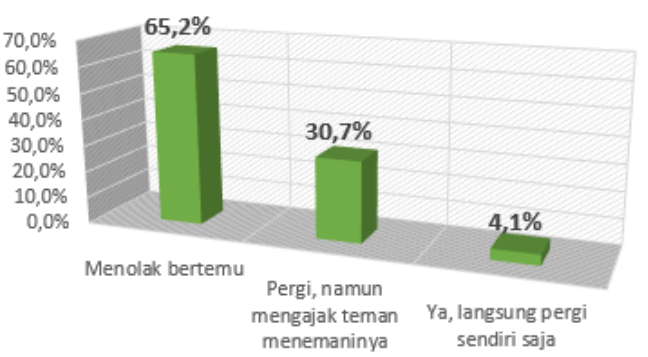

Gambar 5 Persentase orang baru kenal mengajak bertemu

Pada kategori kesadaran pengguna, berdasarkan data kuisioner, didapatkan data bahwa $61.9 \%$ mahasiswa telah mengetahui dan sadar bahwa data kartu kredit anda bisa dicuri via online dan digunakan oleh pihak yang tidak bertanggung jawab, sedangkan $38.1 \%$ belum mengetahuinya. Hal ini cukup menjadi perhatian dikarenakan terdapat $76.8 \%$ mahasiswa yang telah memiliki kartu kredit. Sehingga potensi terjadinya penyalahgunaan kartu kredit cukup tinggi.

Kemudian didapatkan juga informasi bahwa $85.1 \%$ mahasiswa telah mengetahui dan sadar bahwa memberikan data-data pribadi ke internet dapat menyebabkan terjadinya kejahatan dan penipuan online. Hal ini sudah cukup bagus karena hanya $14.6 \%$ mahasiswa yang masih belum mengetahui hal tersebut.

Rata-rata tingkat kesadaran pada kategori media social didapatkan berdasarkan rata-rata jawaban yang dipilih No oleh mahasiswa dari 5 pertanyaan. Hal ini dilakukan karena pilihan No pada kategori ini merupakan pilihan yang menyatakan apakah mahasiswa sadar akan hal tersebut atau tidak. Rata-rata tingkat kesadaran pengguna didapatkan berdasarkan nilai ratarata 3 pertanyaan dengan jawaban "Tahu".

Kemudian juga berdasarkan nilai rata-rata untuk jawaban "mengikuti seluruh saran rekomendasi" sebanyak $57 \%$ sedangkan sisanya "hanya menggunakan saran 
rekomendasi password". Sehingga terdapat indikator yang digunakan untuk mendapatkan nilai rata-rata tingkat kewaspadaan mahasiswa terkait kategori kesadaran pengguna yaitu :

Table 3. Rata-rata tingkat kewaspadaan mahasiswa

\begin{tabular}{|l|l|l|}
\hline No & Kategori & Rata-Rata \\
\hline 1 & Media Sosial & $84.2 \%$ \\
\hline 3 & Kesadaran Pengguna & $72.7 \%$ \\
\hline
\end{tabular}

Berdasarkan tabel 3 diatas, dapat disimpulkan bahwa mahasiswa UMRI telah memiliki tingkat kewaspadaan yang cukup baik. Namun pihak universitas, fakultas dan juga program studi tetap harus memberikan pendampingan, edukasi ataupun sosialisasi bagi mahasiswa yang belum memiliki tingkat kewaspadaan yang baik karena masih ada beberapa persen masih masih belum mempunyai tingkat kewaspadaan yang baik.

\section{SIMPULAN DAN SARAN}

Berdasarkan hasil penelitian yang dilakukan dan berdasarkan hasil kuisioner, maka didapatkan kesimpulan yaitu bahwa mahasiswa UMRI pada jurusan teknik informatika fakultas ilmu komputer rata sudah sadar dan mengetahui bahaya dari cybercrime dengan total nilai ratarata $84,2 \%$ dalam kategori penggunaan media sosial dan kategori kesadaran pengguna sebesar $72,7 \%$. Namun pihak universitas, fakultas dan juga program studi tetap harus memberikan pendampingan, edukasi ataupun sosialisasi bagi mahasiswa yang belum memiliki tingkat kewaspadaan yang baik karena masih ada beberapa persen masih masih belum mempunyai tingkat kewaspadaan yang baik.

\section{TERIMA KASIH}

Terima kasih kepada berbagai pihak yang terlibat dalam penelitian ini hingga tahap akhir. Selain itu ucapan terima kasih kepada Kementerian Riset, Teknologi dan Pendidikan Tinggi yang telah mendukung pendanaan dalam penelitian ini.

\section{DAFTAR PUSTAKA}

[1] P. Batubara, "Tahun 2017, Polisi Tangani 1.763 Kasus Kejahatan Siber," okezone, Jakarta, Dec-2017.

[2] B. Suhariyanto, Tindak Pidana Teknologi Informasi (Cybercrime): Urgensi Pengaturan dan Celah Hukumnya. Jakarta: PT.Raja Grafindo Persada, 2014.

[3] Soni, A. Hafid, and D. Sudyana,
"Analysis of Security Awareness in Using Technology and Social Media at Muhammadiyah University, Riau," Int. J. Comput. Appl., vol. 183, 2019.

[4] L. Mahfiana, "Kesadaran hukum mahasiswa terhadap teknologi dan perkembangannya," Pros. Semin. Nas. Temu Ilm. Jar. Peneliti IAI Darussalam Blokagung Banyuwangi, vol. 1, no. 8, pp. 1-13, 2017.

[5] N. Sulisrudatin, "Analisa Kasus Cybercrime Bidang Perbankan," Ilm. Dirgant., vol. 9, no. 1, pp. 26-39, 2018.

[6] C. Juditha, "( Kasus Love Scams ) Communication Patterns in Cybercrime ( Love Scams Case )," pp. 29-41, 2015.

[7] A. S. Hamsi, F. D. S. Bahry, S. N. M. Tobi, and M. Masrom, "Cybercrime over Internet Love Scams in Malaysia: A Discussion on the Theoretical Perspectives, Connecting Factors and Keys to the Problem," J. Manag. Res., vol. 7, no. 2, p. 169, 2015.

[8] J. Cinta, S. Di, Z. Ismail, and A. Aziz, "Love Scam in Malaysia: The Exploration of Victim Experiences," $J$. Soc. Sci. Humanit., vol. 16, no. 4, pp. 110, 2018.

[9] C. Steven, Cybercrime Vandalizing The Information Society. United Stated of America: Pearson Education Limited., 2016.

[10] A. Nasution, J. J. Hius, and J. Saputra, "Mengenal Dan Mengantisipasi Kegiatan Cybercrime Pada Aktifitas Online Sehari-Hari Dalam Pendidikan, Pemerintahan Dan Industri Dan Aspek Hukum Yang Berlaku," SNIKOM Banda Aceh, no. ISBN: 978-60270467-0-2, 2014.

[10] A. A. Aco and Riskawati;, "Penanganan Kasus Cyber Crime Di Kota Makassar (Studi Pada Kantor Kepolisian Resort Kota Besar Makassar)," J. Supremasi, vol. XI Nomor 1, no. ISSN 1412-517X, 2016 